DEATHS OF DESPAIR AND THE

FUTURE OF CAPITALISM 



\section{Deaths of Despair and the Future of Capitalism}

A N NE CASE

A NGUS DEATON

With a new preface by the authors 


\section{Copyright (C) 2020 by Princeton University Press}

Preface to the paperback edition, copyright (C) 2021 by Princeton University Press

Requests for permission to reproduce material from this work

should be sent to permissions@press.princeton.edu

Published by Princeton University Press

41 William Street, Princeton, New Jersey 08540

6 Oxford Street, Woodstock, Oxfordshire OX2o 1TR

press.princeton.edu

\section{All Rights Reserved}

Epigraph on page 83 from "In a Time" from Just Give Me a Cool Drink of Water 'Fore I Diiie: Poems by Maya Angelou. Copyright $\left({ }_{1} 1971\right.$ by Maya Angelou. Used by permission of Little, Brown Book Group Limited and Random House, an imprint and division of Penguin Random House LLC. All rights reserved.

First paperback edition, 2021

Paperback ISBN 978-o-691-21707-9

Library of Congress Control Number: 2020949713

The Library of Congress has cataloged the cloth edition as follows:

Names: Case, Anne, 1958- author. | Deaton, Angus, author.

Title: Deaths of despair and the future of capitalism / Anne Case, Angus Deaton.

Description: Princeton : Princeton University Press, [2020] | Includes bibliographical references and index.

Identifiers: LCCN 2019040360 (print) | LCCN 2019040361 (ebook) | ISBN 9780691190785 (hardback; alk. paper) | ISBN 9780691199955 (ebook)

Subjects: MESH: Suicide-economics | Socioeconomic Factors | Drug Overdoseeconomics | Capitalism | Educational Status | Politics | United States

Classification: LCC HV6548.U6 (print) | LCC HV6548.U6 (ebook) | NLM HV 6548.U6 | DDC $362.28-\mathrm{dc} 23$

LC record available at https://lccn.loc.gov/2019040360

LC ebook record available at https://lccn.loc.gov/2019040361

British Library Cataloging-in-Publication Data is available

Editorial: Joe Jackson, Jacqueline Delaney

Production Editorial: Terri O'Prey

Jacket/Cover Design: Karl Spurzem

Production: Erin Suydam

Publicity: James Schneider, Caroline Priday

This book has been composed in Arno Pro

Printed in the United States of America 
For Julian, Celestine, Lark, Andrew, Ryan, James, John, Marie, and Will

May they enjoy a world with more fairness and less despair. 
